\title{
Addition of Moringa Leaf Extract and Natural Sweeteners of Palm Sugar to The Characteristics of Moringa Pudding
}

\author{
Ni Luh Putu Dian Windari ", Luh Suriati ${ }^{\text {*** }}$, I Nyoman Rudianta \\ Department of Food Science and Technology Faculty of Agriculture, Warmadewa University, Indonesia \\ *dianwindari93@gmail.com \\ **suryati_luh@yahoo.com
}

\begin{abstract}
Pudding is a type of dessert. It tastes sweet and has a soft texture. Efforts are made on making pudding that can be functional by adding Moringa leaf extract and palm sugar. The purpose of this study was to determine the characteristics of water content, reduced sugar content, $\mathrm{pH}$, texture, and antioxidant activity as well as subjective assessments including aroma, color, texture, and overall acceptance of Moringa pudding added with natural sweeteners of palm sugar. The research was conducted in September 2019-February 2020 at the Food Analysis Laboratory of the Faculty of Agriculture, Warmadewa University, and Udayana University. Using a factorial experiment with a Completely Randomized Design (CRD) consisting of 2 factors: Factor I, Moringa leaf extract concentration $(2.5 \%, 5.0 \%, 7.5 \%$ and $10.0 \%)$. Factor II, the addition of palm sugar $(5.0 \%, 7.5 \%$, and $10.0 \%)$. The objective analysis of pudding produced from the treatment of Moringa leaf extract $10.0 \%$ palm sugar $10.0 \%$ while the subjective assessment of pudding produced from the treatment of Moringa leaf extract $5.0 \%$ palm sugar $10.0 \%$ (like-very like) with the characteristics of pudding Moringa is the water content of the addition of Moringa leaf extract $74.138 \%$ Palm sugar $63.172 \%$, Reducing sugar content adding Moringa leaf extract 15.239\% Palm sugar 15.515\%, pH adding Moringa leaf extract 6.733 Palm sugar does not affect, the texture of adding Moringa leaf extract and Palm sugar $5.612 \mathrm{~N}$ Antioxidant activity of addition of Moringa leaf extract $22.275 \mathrm{mg} / \mathrm{L}$ GAEAC palm sugar $21.676 \mathrm{mg} / \mathrm{L}$ GAEAC.
\end{abstract}

Keywords: moringa pudding, moringa extract, natural sweeteners, palm sugar, characteristic

\section{Introduction}

Pudding is one type of dessert that is generally served at the end of a banquet. As a dessert, pudding is in great demand because of its sweet taste and soft texture [1]. One effort that can be done is to make a pudding that can be functional by adding Moringa leaves that can provide a positive effect on body health. Moringa is known throughout the world as a nutritious plant and the World Health Organization (WHO) has introduced Moringa as an alternative food to overcome the problem of nutrition (malnutrition). In Africa and Asia, Moringa leaves are recommended as a nutrient-rich supplement for breastfeeding mothers and children during infancy. Various parts of Moringa plants such as leaves, roots, seeds, bark, fruit, and flowers act as heart and blood circulation stimulants, have anti-tumor, anti-hypertension, reduce cholesterol, antioxidants, anti-diabetic, anti-bacterial, and anti-fungal [2]. One of the most prominent of the content of Moringa plants is the content of antioxidants, especially in the leaves that contain the highest antioxidants.

Antioxidants contained in Moringa leaves include tannins, steroids, triterpenoids, flavonoids, saponins, interquinones, and alkaloids [3]. Fresh Moringa leaves have antioxidant power 7 times more than vitamin C [4]. One of the flavonoid groups that have Moringa is quercetin, where quercetin has antioxidant strength 4-5 times higher than vitamin C and vitamin E. Dried Moringa leaves per 100 grams contain $7.5 \%$ water, $205 \mathrm{kcal}$ energy, 38.2 grams carbohydrates, 27.1 grams protein, 2.3 
grams fat, 0.9 grams fiber, calcium $2003 \mathrm{mg}$, magnesium $368 \mathrm{mg}$, phosphorus $204 \mathrm{mg}$, copper 0.6 $\mathrm{mg}$, iron $28.2 \mathrm{mg}$, sulfur $870 \mathrm{mg}$, and potassium $1324 \mathrm{mg}$ [5]. The functional food innovation of Moringa leaf pudding is used in people who do not like vegetables in all walks of life and is also good for health because the Moringa leaf pudding feels bitter when sugar is not added but the sugar used in making Moringa leaf pudding is palm sugar as a natural sweetener. In addition, the addition of palm sugar affects the texture of the moringa leaf pudding. The number of calories in coconut sugar in cake dough is even lower by $30 \%$ compared to white sugar. Palm sugar is also suitable for natural sweeteners because palm sugar is free of chemicals in the manufacturing process compared to white sugar. Palm sugar is also referred to as organic sugar. Therefore, the authors examine the "Addition of Moringa Leaf Extract and Natural Sweeteners of Palm Sugar Against the Characteristics of Moringa Pudding".

The formulation of the problem in this study is the characteristics of good moringa pudding seen from the objective and subjective nature of added Moringa leaf extract and natural sweetener palm sugar. Antioxidant activity in moringa pudding with the addition of moringa leaf extract and natural sweeteners of palm sugar not yet determine. The purpose of this research is 1 . To know the characteristics of good moringa pudding seen from the objective and subjective nature added Moringa leaf extract and natural sweetener palm sugar. 2. To determine the antioxidant activity of moringa pudding by adding Moringa leaf extract and natural sweeteners of palm sugar. The benefits of this research are It is expected that the results of this study can provide information about the addition of Moringa leaf extract and palm sugar to produce the characteristics of good Moringa pudding. The hypothesis of this research is the concentration of Moringa leaf extract 5.0\% and the addition of palm sugar $10.0 \%$ and its characteristics namely the concentration of Moringa leaf extract $10.0 \%$ and the addition of $10.0 \%$ palm sugar can produce good Moringa pudding.

\section{Material and Methods}

The research was carried out at the Food Analysis Laboratory of the Faculty of Agriculture, Warmadewa University, and Antioxidant Activity Analysis at the Udayana University Food Analysis Laboratory. The study was conducted for 6 months, from September 2019 - February 2020. This study used a factorial experiment with a Completely Randomized Design (CRD) consisting of 2 factors: Factor I, Moringa leaf extract concentration (2.5\%, 5.0\%, 7.5\%, and 10.0\%). Factor II, the addition of palm sugar $(5.0 \%, 7.5 \%$, and $10.0 \%)$. The variables observed included objective analysis of water content, reducing sugar content, $\mathrm{pH}$, texture, and antioxidant activity. Subjective assessments include tests of aroma, color, texture, taste, and overall acceptance. Each treatment was repeated 2 times to obtain 24 units of the experiment. Data obtained from the objective test is processed by analysis of variance (F test), if the results show a significantly different effect / very real it is followed by a 5\% and 1\% LSD test. While the organoleptic test on texture, color, and taste, and overall acceptance were analyzed by using Duncan's distinguishing test.

The stages of the research consisted of making Moringa leaf extract, Moringa pudding research by adding palm sugar, and pudding quality analysis and data analysis. Moringa leaf extract by making Moringa leaves which are picked directly from the tree are immediately sorted by selecting fresh and not rotten Moringa leaves with a dark green color. Then cleaned and washed so that there is no dirt on the leaves of the Moringa. Then blanch for 5 minutes at $70^{\circ} \mathrm{C}$ on medium heat. Furthermore, in a blender with a water ratio of 1: 1 on a blender for 4 minutes. With medium blender speed. Moringa leaves that have been blended are measured using a measuring cup. And these results are called Moringa leaf extract. 
Moringa Pudding Research Procedure Added to Palm Sugar by Preparing tools and washing the tools used. Then weigh the ingredients. Next prepare the stove and the medium pan then put the swallow instant pudding powder, $1000 \mathrm{ml}$ full cream ultra-liquid milk, and palm sugar, and Moringa leaf extract into the medium pan. Stir until evenly mixed. Heat until boiling for 10 minutes using medium heat. Prepare a plastic mold and the lid. Then enter the pudding that has been cooked then put it in a plastic mold. Let stand for 10 minutes at room temperature. Then close the pudding. after that put it in the refrigerator. Palm sugar pudding is ready to be served and analyzed.

\section{Results and Discussion}

\subsection{Objective Variables}

\subsubsection{Water Content}

Based on analysis of variance showed that the concentration of Moringa leaf extract had a significant effect ( $p<0.05)$, the addition of palm sugar showed a very significant effect $(p<0.01)$ and the interaction showed no significant effect $(p>0.05)$. The average water content of Moringa pudding in the treatment of Moringa leaf extract concentration and the addition of palm sugar can be seen in Table 1 .

Table 1

Moisture Content (\%) Moringa Pudding on Treatment Moringa Leaf Extract Concentration and Addition of Palm Sugar

\begin{tabular}{lllll}
\hline Treatment & \multicolumn{3}{c}{ Palm Sugar } \\
\hline Moringa Leaf Extract & $5.0 \%$ & $7,5 \%$ & $10,0 \%$ & Average \\
\hline $2.5 \%$ & 75.736 & 69.349 & 63.645 & $69.577 \mathrm{~b}$ \\
$5.0 \%$ & 80.643 & 70.760 & 58.487 & $69.963 \mathrm{~b}$ \\
$7.5 \%$ & 78.998 & 69.077 & 63.902 & $70.659 \mathrm{~b}$ \\
$10.0 \%$ & 78.086 & 77.674 & 66.655 & $74.138 \mathrm{a}$ \\
\hline Average & $78.366 \mathrm{a}$ & $71.715 \mathrm{~b}$ & $63.172 \mathrm{c}$ & \\
\hline
\end{tabular}

Information:

1. The average value followed by the same letter in the same line shows an insignificant difference (p>0.05).

2. The average value followed by different letters in the same column shows significant differences $(\mathrm{p}<0.05)$ to very significant $(\mathrm{p}<0.01)$.

From the results of the study, it can be seen that the concentration of Moringa leaf extract $10.0 \%$ produces the highest water content that is $74.138 \%$ which is significantly different from other treatments. This is because the concentration of Moringa leaf extract will increase the water content of the product more. After all, in the process of making Moringa leaf extract do the addition of water. Water content is the amount of water contained in a material expressed in percent. Water content is also one of the most important characteristics of food because water can affect the appearance, texture, and taste of food. The water content in food also determines the freshness and durability of the food, but if the water content is too high, it makes it easy for bacteria, molds, and yeast to multiply, so there will be changes in food [6][7]. While the treatment of palm sugar addition shows the lowest water content in the treatment of adding 10\% sugar which is $63.172 \%$ which is statistically significantly different from other treatments. This is due to the nature of sugar which can bind water to an ingredient. The ability to bind water is a trait that causes sugar to reduce water content in food added [8]. Figure 1 is a graph of water content at the concentration of Moringa leaf extract and Figure 2 is a graph of water content on the addition of palm sugar. 


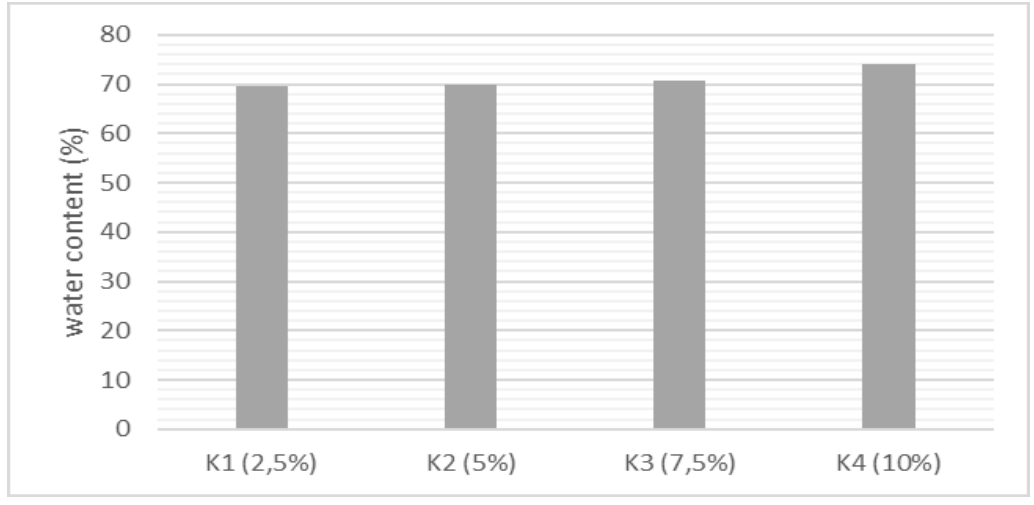

Figure 1

Graph of water content at the concentration of Moringa leaf extract

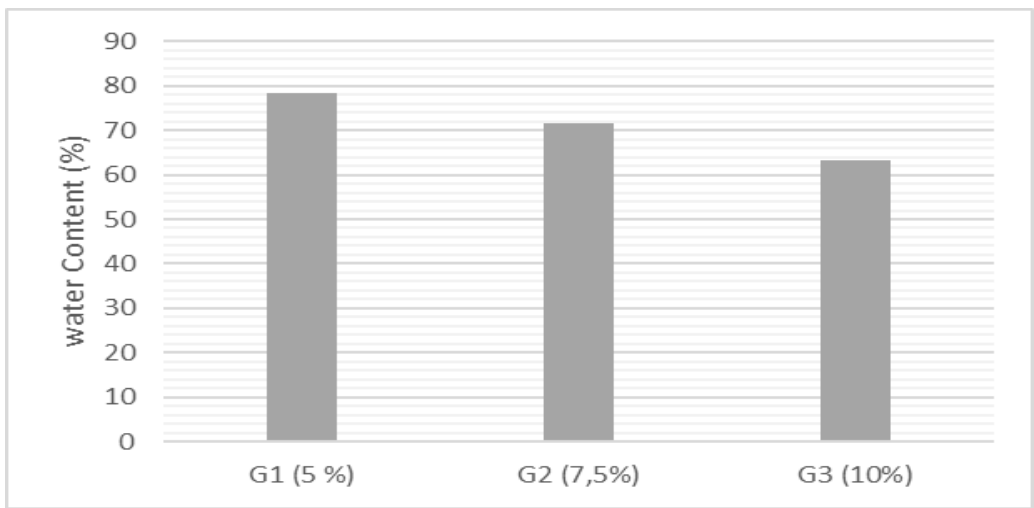

Figure 2

Graph of water content on the addition of palm sugar

\subsubsection{Reducing Sugar Content}

Based analysis of variance showed that the concentration of Moringa leaf extract with the addition of palm sugar showed a very significant effect $(\mathrm{p}<0.01)$ and the interaction showed no significant effect $(\mathrm{p}>0.05)$. The average sugar content of Moringa pudding reduction in the treatment of Moringa leaf extract concentration and the addition of palm sugar can be seen in Table 2.

Table 2

Reduced Sugar (\%) Moringa Pudding on Moringa Leaf Extract Concentration Treatment and Addition of Palm Sugar

\begin{tabular}{ccccc}
\hline Treatment & \multicolumn{5}{c}{ Palm Sugar } \\
\hline Moringa Leaf Extract & $5.0 \%$ & $7.5 \%$ & $10.0 \%$ & Average \\
\hline $2.5 \%$ & 13.276 & 13.675 & 14.925 & $13.959 \mathrm{~b}$ \\
$5.0 \%$ & 13.565 & 14.332 & 15.169 & $14.355 \mathrm{~b}$ \\
$7.5 \%$ & 13.850 & 14.995 & 15.700 & $14.848 \mathrm{ab}$ \\
$10.0 \%$ & 14.113 & 15.339 & 16.265 & $15.239 \mathrm{a}$ \\
\hline Average & $13.701 \mathrm{c}$ & $14.585 \mathrm{~b}$ & $15.515 \mathrm{a}$ & \\
\hline
\end{tabular}

Information:

1. The average value followed by the same letter in the same line shows an insignificant difference ( $\mathrm{p}>0.05)$.

2. The average value followed by different letters in the same column shows significant differences $(\mathrm{p}<0.050)$ to very significant $(\mathrm{p}<0.01)$. 
In the addition of palm sugar treatment, the highest G3 treatment is $10.0 \%$ with an average reducing sugar content of $15.515 \%$ which is significantly different from other treatments. From the research data, it can be seen that the addition of sugar can increase the level of reducing pudding sugar. This is due to the palm sugar used also contains reducing sugar so that the addition of palm sugar increases the sugar content of Moringa leaf reduction. Reducing sugar is all sugars that can reduce due to the presence of free aldehyde or ketone groups. Aldehydes can be oxidized directly through redox reactions. However, ketone groups cannot be oxidized directly, ketone groups, but must be converted to aldehydes by tautomeric transfer which moves the carbonyl group to the end of the chain. Monosaccharides that include reducing sugars include glucose, fructose, glyceraldehyde, and galactose. For disaccharides, for example, are lactose and maltose. While the non-reducing sugars are sucrose. Sucrose is a disaccharide with an $\alpha$-D-glucose molecule that is bound by a $\beta$-Dfructose molecule. Sucrose is not a reducing sugar group because it does not have a free carbonyl group. Glucose and fructose are the sucrose monosaccharides. Both of these monosaccharides are reducing sugar [9]. The content of reducing sugars and sucrose in palm sugar is very closely related, where the reducing sugars are generally a mixture of glucose and fructose, monosaccharides which are the inversion results of sucrose. This inversion process can occur shortly after the sap is tapped until the sap is cooked into sugar. In fresh roomie during the sucrose inversion process is usually caused by microbial activity that produces invertase [10].

Moringa leaf extract extracts of $10.0 \%$ produced the highest reducing sugar content of $15.239 \%$ which was not significantly different from the treatment of $7.5 \%$ Moringa leaf extract concentration which was $14.848 \%$ and significantly different from the treatment of Moringa leaf extract concentration of $2.5 \%$ and 5, $0 \%$ with reducing sugar content respectively are $13.959 \%$ and $14.355 \%$. The higher concentration of Moringa leaf extract can increase the level of reducing sugar in the Moringa pudding. This is because the Moringa leaves contain carbohydrates by 13.8 grams [4] so that the addition of Moringa leaves can increase the sugar content of Moringa pudding reduction. Figure 3 is a graph of reducing sugar content in the concentration of Moringa leaf extract and Figure 4 is a graph of reducing sugar content on palm sugar addition.

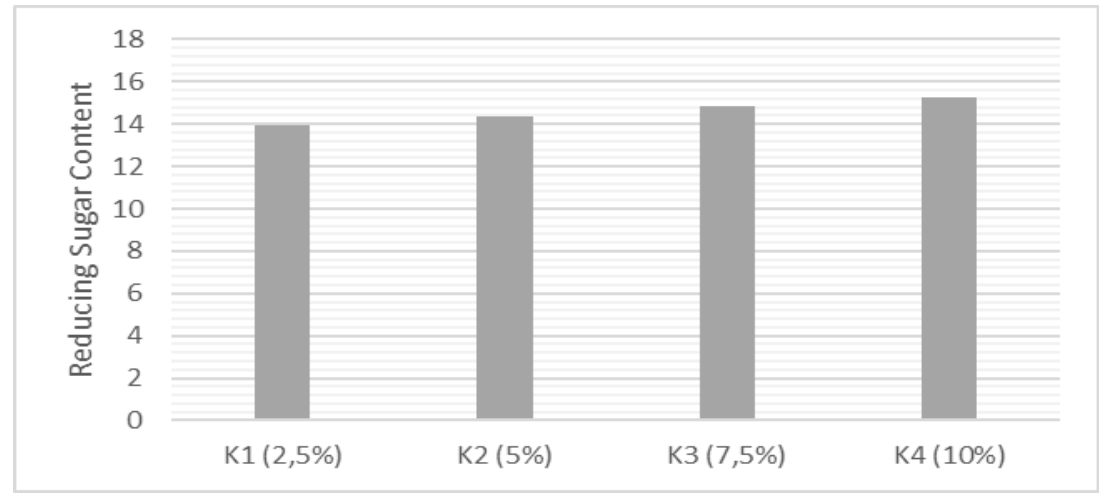

Figure 3

Graph of reducing sugar content in the concentration of Moringa leaf extract 


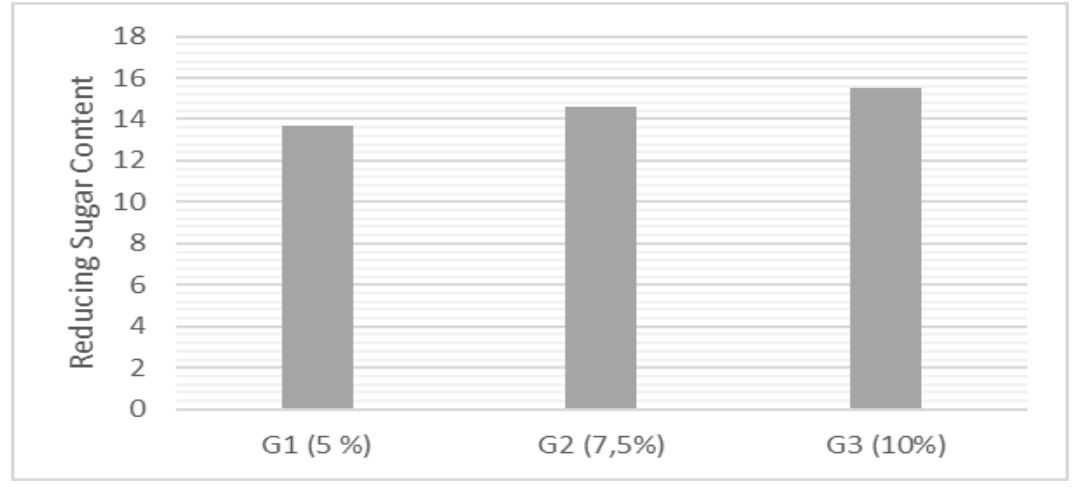

Figure 4

Graph of reducing sugar content on palm sugar addition.

\subsection{3 pH}

Based on analysis of variance showed that the concentration of Moringa leaf extract had a significantly different effect $(\mathrm{p}<0.01)$, while the addition of palm sugar showed a different effect that was not significant $(p>0.05)$ and the interaction gave a different effect that was not significant $(p>$ 0.05 ) to the $\mathrm{pH}$ level of the moringa leaf pudding. The average $\mathrm{pH}$ of Moringa pudding in the treatment of Moringa leaf extract concentration and the addition of palm sugar can be seen in Table 3.

Table 3

the $\mathrm{pH}$ of Moringa Pudding on Moringa Leaf Extract Concentration Treatment and Addition of

Palm Sugar

\begin{tabular}{ccccc}
\hline Treatment & \multicolumn{3}{c}{ Palm Sugar } \\
\hline Moringa Leaf Extract & $5.0 \%$ & $7.5 \%$ & $10.0 \%$ & Average \\
\hline $2.5 \%$ & 6.215 & 6.260 & 6.285 & $6.253 \mathrm{c}$ \\
$5.0 \%$ & 6.640 & 6.670 & 6.680 & $6.663 \mathrm{~b}$ \\
$7.5 \%$ & 6.720 & 6.735 & 6.725 & $6.727 \mathrm{ab}$ \\
$10.0 \%$ & 6.700 & 6.760 & 6.740 & $6.733 \mathrm{a}$ \\
\hline Average & $6.569 \mathrm{a}$ & $6.606 \mathrm{a}$ & $6.608 \mathrm{a}$ & \\
\hline
\end{tabular}

Information:

1. The average value followed by the same letter in the same line shows an insignificant difference (p>0.05).

2. The average value followed by different letters in the same column shows significant differences $(\mathrm{p}<0.050)$ to very significant $(\mathrm{p}<0.01)$.

The $\mathrm{pH}$ value of Moringa pudding due to the addition of palm sugar showed no significant effect with all treatments. This shows that the addition of sugar does not affect the $\mathrm{pH}$ value of the Moringa pudding. The highest $\mathrm{pH}$ value obtained at $10.0 \%$ Moringa leaf extract concentration is 6.733 which is not significantly different from the treatment of $7.5 \%$ Moringa leaf extract concentration which is 6.727 and significantly different from the treatment of Moringa leaf extract with $\mathrm{pH}$ values 6.663 and 6.253. This is because Moringa leaves have a neutral $\mathrm{pH}$ that tends towards the base (7.0 to 8.0) and has a low total acid value. According to [11] the percentage concentration of moringa leaf extract is known to make the pudding $\mathrm{pH}$ increase. This is possible because Moringa leaf extract has a $\mathrm{pH}$ that leads to a neutral range of 5.8-6.0. Figure 5 is a $\mathrm{pH}$ chart on the concentration of Moringa leaf extract. 


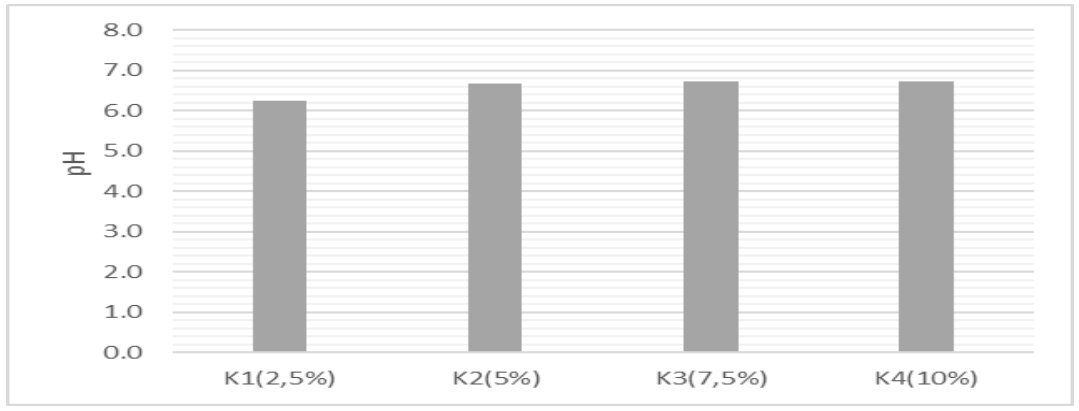

Figure 5

$\mathrm{pH}$ chart on the concentration of Moringa leaf extract.

\subsubsection{Texture}

Based on analysis of variance showed that the concentration of Moringa leaf extract had a very significant effect ( $\mathrm{p}<0.01$ ), while the addition of palm sugar showed a different effect that was not significant $(p>0.05)$ and the interaction had a very significant effect $(p<0.01)$ to the texture of Moringa pudding. The average value of the texture of Moringa pudding in the treatment of Moringa leaf extract concentration and the addition of palm sugar can be seen in Table 4.

Table 4

Texture (N) Moringa Pudding on Moringa Leaf Extract Concentration Treatment and Addition of Palm Sugar

\begin{tabular}{cccc}
\hline Treatment & \multicolumn{3}{c}{ Palm Sugar } \\
\hline Moringa Leaf Extract & $5.0 \%$ & $7.5 \%$ & $10.0 \%$ \\
\hline $2.5 \%$ & $3.736 \mathrm{a}$ & $4.374 \mathrm{a}$ & $3.959 \mathrm{a}$ \\
& $(\mathrm{ab})$ & $(\mathrm{a})$ & $(\mathrm{b})$ \\
$5.0 \%$ & $4.841 \mathrm{a}$ & $4.947 \mathrm{a}$ & $3.146 \mathrm{~b}$ \\
& $(\mathrm{a})$ & $(\mathrm{a})$ & $(\mathrm{bc})$ \\
$7.5 \%$ & $3.650 \mathrm{~b}$ & $4.150 \mathrm{~b}$ & $5.612 \mathrm{a}$ \\
& $(\mathrm{b})$ & $(\mathrm{a})$ & $(\mathrm{a})$ \\
$10.0 \%$ & $4.207 \mathrm{a}$ & $2.467 \mathrm{~b}$ & $2.734 \mathrm{~b}$ \\
& $(\mathrm{ab})$ & $(\mathrm{b})$ & $(\mathrm{c})$ \\
\hline BNT $(0.05)$ & 1.125 & & \\
\hline
\end{tabular}

\section{Information:}

1. The average value followed by the same letter in the same row and column shows no significant difference ( $p>0.05)$.

2. Different letters below the mean value in the same column show significantly different $(p<0.05)$

From the results of the study, it was seen that the highest texture was obtained in the treatment of Moringa leaf extract concentration of $7.5 \%$ and the addition of palm sugar $10.0 \%$, with a texture value of $5.612 \mathrm{~N}$ (Newton). The texture of the pudding is influenced by the additional ingredients provided. Sugar has a thick nature when heated so that the more added sugar will improve the texture of the Moringa pudding. Adding sugar to the pudding is not only to produce sweetness although this trait is very important. So, sugar is to perfect the sour taste, the flavor also gives you thickness. The high solubility of sugar, can reduce relative humidity and water-binding ability are properties that cause sugar to be used in food preservation while according to [12] Adding sugar to the pudding in addition to sweeteners as well for texture formation when there is pectin in a mixture of water, sugar will affect the balance of pectin and water because sugar functions as a dehydrating agent that reduces water in the surface of pectin. And the addition of Moringa leaves can improve the texture as well as a statement [13] the higher the protein content in the pudding, the thickness (viscosity) of the pudding increases. 
One of the texture parameters in food products is elasticity. The elasticity is the physical properties of the product in terms of resistance to breaking due to compressive force [14]. Chewy and hard nature are both expressed resistances to breaking. The difference is the hard nature to express the nature of objects or food products that are not deformation, while the rubbery nature is the rheological nature of plastic food products that are deforming [15][16]. The elasticity involves texture, the ease of initial tooth penetration into food products, then chewing into smaller pieces and the amount of residue left after mastication [17]. A softer pudding texture can be obtained by adding a volume of water so that the nature of the pudding becomes more slippery and springy. Figure 6 is a texture graph on the concentration of Moringa leaf extract and the addition of palm sugar.

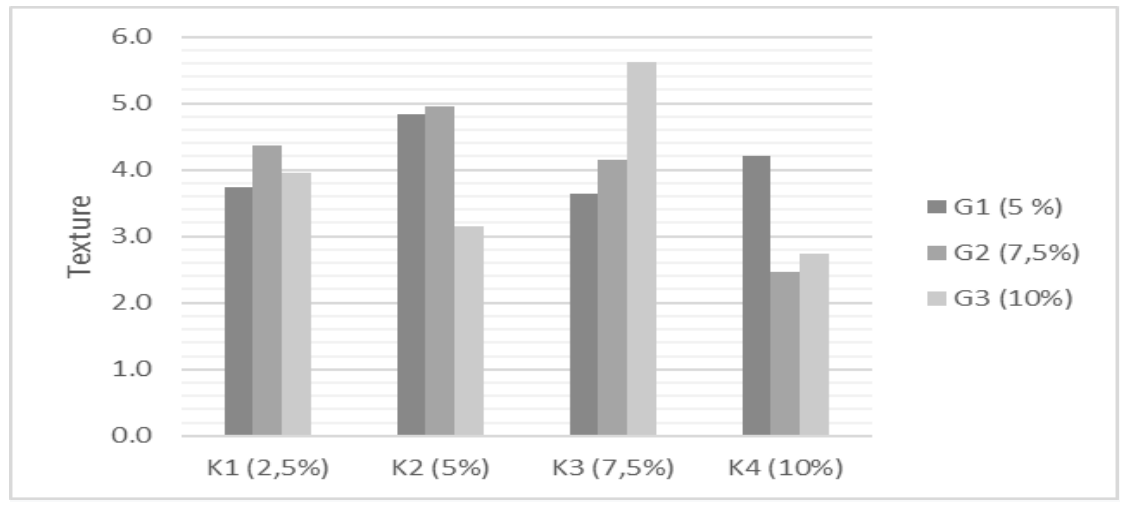

Figure 6

The texture on the concentration of Moringa leaf extract and the addition of palm sugar

\subsubsection{Antioxidant Activity}

Based on analysis of variance showed that the concentration of Moringa leaf extract had a significantly different effect ( $\mathrm{p}<0.01$ ), while the addition of palm sugar showed a significantly different effect $(\mathrm{p}<0.05)$ and the interaction had a non-significant effect $(\mathrm{p}>0.05)$ to the antioxidant activity of Moringa pudding. The average value of antioxidant activity from the effect of the concentration of Moringa leaf extract and the addition of palm sugar can be seen in Table 5.

Table 5

Antioxidant Activity (mg / L GAEAC) Moringa Pudding on the Treatment of Moringa Leaf Extract Concentration and Addition of Palm Sugar

\begin{tabular}{ccccc}
\hline Treatment & \multicolumn{5}{c}{ Palm Sugar } \\
\hline Moringa Leaf Extract & $5.0 \%$ & $7.5 \%$ & $10.0 \%$ & Average \\
\hline $2.5 \%$ & 16.620 & 16.905 & 16.710 & $16.745 \mathrm{~b}$ \\
$5.0 \%$ & 15.995 & 14.530 & 16.360 & $15.628 \mathrm{~b}$ \\
$7.5 \%$ & 22.555 & 13.930 & 27.920 & $21.468 \mathrm{ab}$ \\
$10.0 \%$ & 20.945 & 20.165 & 25.715 & $22.275 \mathrm{a}$ \\
\hline Average & $19.029 \mathrm{ab}$ & $16.383 \mathrm{~b}$ & $21.676 \mathrm{a}$ & \\
\hline
\end{tabular}

Information:

1. The average value followed by the same letter in the same row and column shows no significant difference ( $p>0.05)$.

2. The average value followed by different letters in the same row and column shows significant differences $(\mathrm{p}<0.050)$ to very real $(\mathrm{p}<0.01)$.

The highest antioxidant value of Moringa pudding was obtained in the treatment of adding palm sugar $10.0 \%$ namely antioxidant activity as much as $21.676 \mathrm{mg} / \mathrm{L}$ GAEAC (Galic Acid Equivalent Antioxidant Capacity) which was not significantly different from the treatment of adding palm sugar 
$5.0 \%$, namely $19.029 \mathrm{mg} / \mathrm{L}$ GAEAC and significantly different from the treatment of adding palm sugar $7.5 \%$, which was $16.383 \mathrm{mg} / \mathrm{L}$ GAEAC. The higher the addition of sugar tends to increase the antioxidant activity of Moringa pudding because in palm sugar there are a lot of antioxidants. The ability of these antioxidants can ward off free radicals so that they can protect the body from the threat of dangerous diseases such as skin cancer [17].

The highest antioxidant activity was obtained at 10\% Moringa leaf extract concentration, 22.275 mg / L GAEAC which was not significantly different from the treatment of $7.5 \%$ Moringa leaf extract, namely $21.468 \mathrm{mg} / \mathrm{L}$ GAEAC and significantly different from the treatment of Moringa leaf extract concentration with antioxidant activity value. $16,745 \mathrm{mg} / \mathrm{L}$ GAEAC and $15.628 \mathrm{mg} / \mathrm{L}$ GAEAC, respectively. The more concentration of Moringa leaf extract increases the antichosid activity of Moringa pudding This is because Moringa leaves have quite high antioxidant activity, namely phenol compounds.

The phenol compound is a compound that has one hydroxyl group in its constituents, while phenolic has more than one hydroxyl group [18]. Phenol compounds have many functional groups which in free conditions or aglycones cause higher total phenol levels [19]. Phenols have a broad spectrum with solubility in a different solvent caused by hydroxyl groups in these compounds with different quantities and positions [20]. If the content of phenolic compounds in the sample is high, the antioxidant activity is also high because of an increase in total phenols so that it can be said that there is an ongoing antioxidant activity [21]. Phenols are abundant in plants and when extracted can be soluble in alcohol [11]. Phenol compounds have properties that can damage cell membranes resulting in stunted cell growth or death due to changes in cell permeability [22]. Phenol acts as a major contributor to the antioxidant activity of moringa [23]. Moringa Oleifera, especially the leaves, contain high antioxidants. Some of the main phenolic bioactive compounds are flavonoid groups such as quercetin, kaempferol, and others. Quercetin is a powerful antioxidant whose strength is 4-5 times higher compared to vitamin $\mathrm{C}$ and vitamin $\mathrm{E}$ which are known as potential vitamins [5]. Antioxidants in Moringa leaves have the activity of neutralizing free radicals to prevent oxidative damage to most biomolecules and produce significant protection against oxidative damage [24]. Figure7 is a graph of antioxidant activity at the concentration of Moringa leaf extract and Figure 8 is a graph of antioxidant activity on the addition of palm sugar.

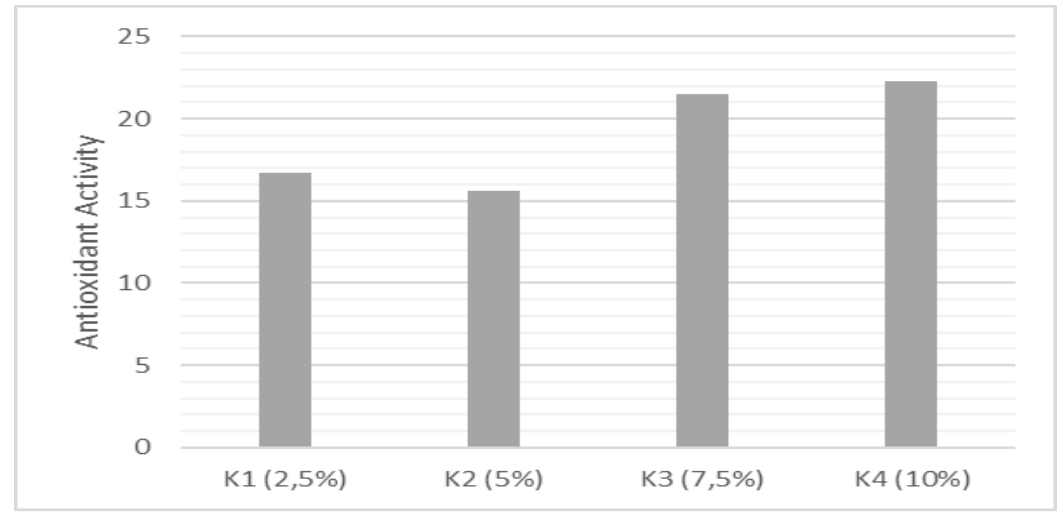

Figure 7

Graph of antioxidant activity at the concentration of Moringa leaf extract 


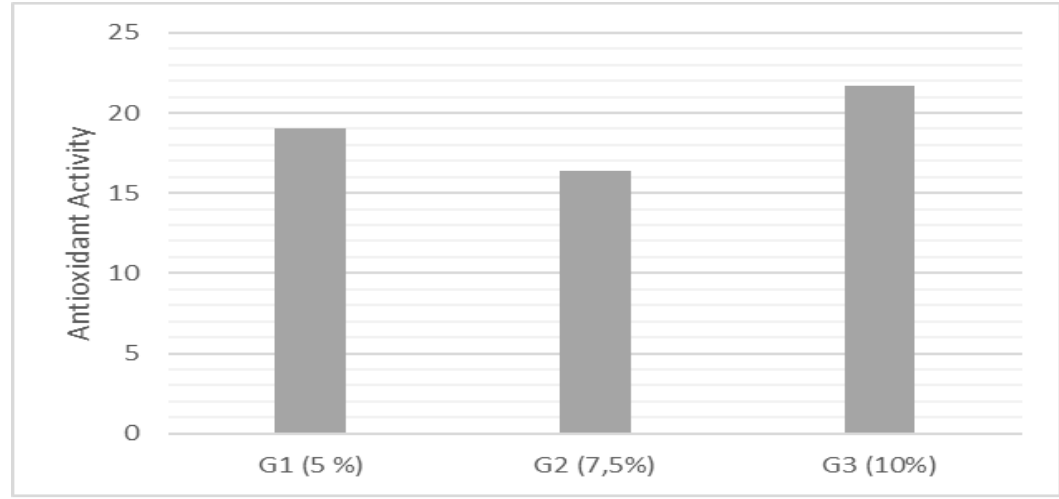

Figure 8

Graph of antioxidant activity on the addition of palm sugar

\subsection{Subjective Variable}

The average value of the panelists' preference level for color, taste, texture, and overall acceptance of Moringa pudding resulting from the concentration of Moringa leaf extract and the addition of palm sugar can be seen in Table 6 below.

Table 6

Subjective Assessment of Moringa Pudding

\begin{tabular}{ccccc}
\hline Treatment & Colour & Taste & Texture & $\begin{array}{c}\text { Overall } \\
\text { Acceptance }\end{array}$ \\
\hline K1G1 & $2.47 \mathrm{c}$ & $1.87 \mathrm{abc}$ & $2.60 \mathrm{~d}$ & $2.87 \mathrm{~b}$ \\
K1G2 & $1.93 \mathrm{c}$ & $2.40 \mathrm{a}$ & $3.13 \mathrm{bcd}$ & $3.27 \mathrm{ab}$ \\
K1G3 & $1.93 \mathrm{c}$ & $2.33 \mathrm{a}$ & $3.40 \mathrm{abc}$ & $3.53 \mathrm{ab}$ \\
K2G1 & $3.33 \mathrm{~b}$ & $1.67 \mathrm{bc}$ & $2.73 \mathrm{~cd}$ & $2.87 \mathrm{~b}$ \\
K2G2 & $1.93 \mathrm{c}$ & $2.33 \mathrm{a}$ & $3.07 \mathrm{bcd}$ & $3.47 \mathrm{ab}$ \\
K2G3 & $2.00 \mathrm{c}$ & $2.20 \mathrm{ab}$ & $3.87 \mathrm{a}$ & $3.67 \mathrm{a}$ \\
K3G1 & $3.60 \mathrm{ab}$ & $2.00 \mathrm{abc}$ & $2.93 \mathrm{bcd}$ & $2.93 \mathrm{ab}$ \\
K3G2 & $2.33 \mathrm{c}$ & $2.07 \mathrm{abc}$ & $3.07 \mathrm{bcd}$ & $3.27 \mathrm{ab}$ \\
K3G3 & $2.27 \mathrm{c}$ & $2.27 \mathrm{ab}$ & $2.73 \mathrm{~cd}$ & $2.93 \mathrm{ab}$ \\
K4G1 & $4.20 \mathrm{a}$ & $1.47 \mathrm{c}$ & $2.60 \mathrm{~d}$ & $2.73 \mathrm{~b}$ \\
K4G2 & $3.67 \mathrm{ab}$ & $1.80 \mathrm{abc}$ & $3.20 \mathrm{abcd}$ & $3.20 \mathrm{ab}$ \\
K4G3 & $3.27 \mathrm{~b}$ & $2.40 \mathrm{a}$ & $3.53 \mathrm{ab}$ & $3.47 \mathrm{ab}$ \\
\hline
\end{tabular}

Information:

1. The average value followed by the same letter in the same column shows no significant difference $(\mathrm{p}>0.05)$.

2. The average value followed by different letters in the same column shows significant differences $(\mathrm{p}<0.05)$ to very significant $(\mathrm{p}<0.01)$.

\subsubsection{Colour of Moringa Pudding}

Based analysis of variance showed that the effect of the treatment of Moringa leaf extract concentration and the addition of palm sugar had a very significant effect $(\mathrm{p}<0.01)$ on the color of Moringa pudding. The highest average value of panelists' preference was obtained in the treatment of $10.0 \%$ Moringa leaf extract concentration with the addition of $5.0 \%$ palm sugar ie 4.20 which was significantly different from the treatment of $7.5 \%$ Moringa leaf extract concentration with the addition of 5.0 palm sugar \% is 3.60 and the treatment concentration of Moringa leaf extract is $10.0 \%$ with the addition of palm sugar $7.5 \%$ which is 3.67 . With a range of very brownish-green grades. This is because the addition of $10.0 \%$ Moringa leaf extract produces a very green color but added with $5.0 \%$ palm sugar to brownish green. Moringa is one food that contains chlorophyll along with 
so many other nutrients. Dark green vegetables and spices such as romaine lettuce, spinach, and parsley are excellent sources of chlorophyll, but they do not provide as many other nutrients as Moringa [25].

\subsubsection{Taste of Moringa Pudding}

Based analysis of variance showed that the effect of the treatment of Moringa leaf extract concentration and the addition of palm sugar had a very significant effect $(\mathrm{p}<0.01)$ on the taste of Moringa pudding. The highest average value of panelist preference was obtained in the treatment of $2.5 \%$ Moringa leaf extract concentration with the addition of $7.5 \%$ palm sugar and $10.0 \%$ Moringa leaf extract concentration treatment with the addition of $10.0 \%$ palm sugar that is 2.40 different very significant to the treatment of Moringa leaf extract concentration with the addition of other palm sugar. With a range of unpleasant or unpleasant values. This is because the addition of a little Moringa leaf extract from other Moringa leaf extract is $2.5 \%$ so the taste does not smell, if in large quantities it will taste bitter on the pudding and $7.5 \%$ added palm sugar which adds flavor to the Moringa pudding.

\subsubsection{Texture of Moringa Pudding}

Based analysis of variance showed that the effect of the treatment of Moringa leaf extract concentration and the addition of palm sugar had a very significant effect $(\mathrm{p}<0.01)$ on the texture of Moringa pudding. The highest average value of panelist preference was obtained in the treatment of $5.0 \%$ Moringa leaf extract concentration with the addition of $10.0 \%$ palm sugar ie 3.87 which was very significantly different from the treatment of Moringa leaf extract concentration with the addition of other palm sugar. With a very soft-hard value range. The difference in the texture of the pudding is due to the influence of the concentration of Moringa leaf extract and the addition of palm sugar. The texture of the pudding is determined by the viscosity of the pudding, which is the degree of viscosity of a food product. Viscosity is influenced by the concentration of thickener added in this case is powder. Viscosity is said to be the endurance provided by a liquid [26]. Viscosity in Moringa pudding is determined by the concentration of pudding powder and the concentration of Moringa leaf extract and palm sugar. Pudding powder has the main content in the form of carrageenan which functions as a gel-forming material [27]. The concentration of Moringa leaf extract is not too much namely $5.0 \%$ which makes the texture of the Moringa pudding is not too hard even though added palm sugar as much as $10.0 \%$.

\subsubsection{Overall Acceptance of Moringa Pudding}

Based analysis of variance showed that the effect of the treatment of Moringa leaf extract concentration and the addition of palm sugar had a significant effect $(p<0.050)$ on the overall acceptance of Moringa pudding. The highest average value of panelists' preference was obtained in the treatment of 5.0\% Moringa leaf extract concentration with the addition of $10.0 \%$ palm sugar that is 3.67 with a range of likes-very likes that were significantly different from the treatment of $2.5 \%$ Moringa leaf extract concentration. with the addition of $5.0 \%$ palm sugar that is 2.87 , the concentration of Moringa leaf extract $5.0 \%$ with the addition of $5.0 \%$ palm sugar that is 2.87 , and the concentration of Moringa leaf extract $10 \%$ with the addition of $5.0 \%$ palm sugar that is 2.73 while not significantly different in the concentration of Moringa leaf extract and the addition of other palm sugar. 


\section{Conclusion}

Based on the results of the study it can be concluded as follows: The best treatment for this moringa pudding is the treatment of 5.0\% Moringa leaf extract concentration adding $10 \%$ palm sugar (like-very like) with the characteristics of Moringa pudding is the water content concentration of Moringa leaf extract $74.138 \%$ addition of $63.172 \%$ palm sugar, content reducing sugar concentration of Moringa leaf extract $15.239 \%$ addition of palm sugar $15.515 \%$, $\mathrm{pH}$ of concentration of Moringa leaf extract 6.733 addition of palm sugar did not affect, the texture of the concentration of Moringa leaf extract and addition of palm sugar 5.612 N. Antioxidant activity concentration of Moringa leaf extract $22.275 \mathrm{mg}$ / L GAEAC addition of palm sugar $21.676 \mathrm{mg} / \mathrm{L}$ GAEAC.

\section{Acknowledgments}

The authors are grateful to the Rector of Warmadewa University, for supporting the project and also to all colleagues that have assisted in this project.

\section{References}

[1] Darmawan, M., Peranginangin, R., Syarief, R., Kusumaningrum, I., Fransiska, D. (2014). The Effect of Adding Carrageenan for Instan Pudding Flour Formulation, 83-95.

[2] Krisnadi, A .D. (2015). Moringa oleifera. Jawa Tengah: Kelorina.com.

[3] Hardiyanthi, F, (2015), Pemanfaatan Aktivitas Antioksidan Ekstrak Daun Kelor (Moringa oleifera) Dalam Sediaan Hand And Body Cream, Skripsi, Program Studi Kimia. Fakultas Sains dan Teknologi. Universitas Islam Negeri Syarif Hidayatullah: Jakarta.

[4] Fuglie. L., (2001). The Miracle Tree: The Multiple Attributes Moringa, Dakar

[5] Sutrisno. (2011). http://Kekuatan-antioksidan-pada-daun-kelor.com. Akses : 22 oktober 2017

[6] Winarno, F. G. (1997). Kimia Pangan dan Gizi. Jakarta: Gramedia Pustaka Utama

[7] Suriati, L., Utama, I M. S., Harsojuwono, B. A., Gunam, I.B.W. (2020). Physicochemical characteristics of fresh-cut tropical fruit during storage. Int. J. of Advance Science and Engineering Information Technology. 10(4): 1731-1736.

[8] Engka. (2016). Effect of Sucrose Concentration and Glucose Syrup on Chemical and Sensory Properties of Wuluh Hard Fruit Candy (Averrhoa Bilimbi. L). Journal of Agricultural Technology, Faculty of Agriculture, Sam Ratulangi University. 7(3):49-58

[9] Junk, W.R. dan H.M.Pancoast. (1980). Handbook of Sugar. Avi Publishing Company. Inc. Westport, Connecticut.

[10] Imanda MR. (2007). Kajian Pengaruh suhu dan waktu Penyimpanan terhadap Karakteristik Mutu Produk Sirup Gula Invert dari gula Palma (Skripsi). Institut Pertanian Bogor.

[11] Yulianti, R. (2008). Pembuatan Minuman Jeli Daun Kelor (Moringa Oleifera Lamk) Sebagai Sumber Fitamin C dan B-Karoten. Skripsi: Bogor: Fakultas Pertanian Institut Pertanian Bogor.

[12] Gardjito dan Sari, (2005). Pengaruh Penamb-ahan Asam Sitrat Dalam Pembuatan Manisan Kering Labu Kuning (Cucurbita maxima) Terhadap Sifat-Sifat Produknya, Jurnal, Fakultas Teknologi Pertanian. Universitas Gajah Mada, Yogyakarta.

[13] Wardhani, D.H, Maharani, D, C \& prasetyo E, A. (2015). Kajian Pengaruh cara Pembuatan Susu Fermentasi terhadap Karakteristik Yoghurt Jagung Manis. Jurnal Momentum Vol 11 (1): 7-12.

[14] Putri AFE. (2009). Sifat Fisik dan Organoleptik Bakso Daging Sapi pada Lama Postmortem yang Berbeda dengan Penambahan Karagenan. [Skripsi]. Bogor (ID): Fakultas Peternakan, Institut Pertanian Bogor

[15] Suriati, L., Utama, I M. S., Harsojuwono, B. A., Gunam, I.B.W. (2020). Incorporating additives for the stability of Aloe gel potentially as an edible coating. J. AIMS Agriculture and Food. 5(3): 327-336.

[16] Suriati, L., Utama, I M.S., Harsojuwono, B. A., dan Gunam, I B. W. (2020). Ecogel Incorporated with Nano-additives to Increase Shelf-life of Fresh-cut Mango. Journal of Applied Horticulture, 22(3): 189195.

[17] Suheri E. (2016). Gula aren atau gula merah sangat manjur untuk mengobati beragam penyakit. Dan untuk daya tahan tubuh. http://www.erwinsuheri.com/2016/06/gula-aren-atau-gula-merah-sangat manjur.html (06 Juni 2016 ). Kesehatan blogekstra.com/supangkat/khasiat-dan-manfaat-gulaaren.html. 
[18] Pangestuty, A. (2016). Uji aktivitas antioksidan dan penetapan kadar fenolik total fraksi etil asetat ekstrak etanol buah buni [Antidesma bunius L. (Spreng)] dengan metode 2,2-difenil-1- pikrilhidrazil (DPPH) dan metode folinciocalteu. Universitas Sanata Dharma.

[19] Deore SL, Khadabadi SS, Baviskar BA, Khadabadi SS, Khagenbam RA, Koli US, Daga NP, Gadbail PA, Jain PA. (2009). In vitro antioxidant activity and phenolic content of Croton caudatum. International Journal of Chemical Technology Research, 1(2), P. 174-176.

[20] Pambayun. (2007). Fenol. Http://pambayun.blogspot.com/. Diakses tanggal 13 april 2014.

[21] Toripah, S.S., Abidjulu, J. \& Wehantouw, F. (2014). Aktivitas antioksidan dan kandungan total fenolik ekstrak daun kelor (Moringa Oloefera Lam.). Pharmacon Jurnal Ilmiah Farmasi, 3. 37-43.

[22] Kumalasari, E \& S. Nanik. (2011). Aktivitas Antifungi Ekstrak Etanol Batang Binahong (Anredera cordifolia (Tenore) Steen.) Terhadap Candida albicans serta Skrinning Fitokimia

[23] Fitri, A. T., Toharmat, D. A. Astuti dan H. Tamura. (2015). The potential use of secondary metabolites in moringa oleifera as an antioxidant source. Media Peternakan. Bogor. 38 ( 3 ) : $169-175$.

[24] Hardiyanthi, F. (2015). Utilization of Antioxidant Activity of Moringa oleifera Leaf Extracts in Hand and Body Cream, Thesis of Chemical Study Program. Faculty of Science and Technology. Syarif Hidayatullah State Islamic University: Jakarta.

[25] Kurniasih. (2013). Khasiat dan Manfaat Daun Kelor Untuk Penyembuhan Berbagai Penyakit.Yogyakarta: Pustaka Baru Press.

[26] Fardiaz D. (1989). Hidrokoloid. Laboratorium Kimia dan Biokimia Pangan. [skripsi]. Bogor: Pusat Antar Universitas Pangan dan Gizi, Institut Pertanian Bogor. Bogor.

[27] Noer H. (2006). Hidrokoloiddalam Pembuatan Jelly Drink. Food Review. Vol 1 Edisi 2 Maret 2006. 